\title{
Kan utviklingen i mobilitet og reisevaner fortelle noe om likestilling?
}

\section{Af RANDi JohanNe HJORTHOL}

Kvinder og mands rejsevaner og rejsetyper er knyttet til sociale forventinger og normer. Analyser af kønnet mobilitet viser, at transport - $i$ bred forstand - kan vere et barometer på dagliglivets ligestilling.

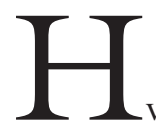

va har mobilitet eller reisevaner med likestilling å gjøre? Er ikke transport et "ukjønnet" område? I denne artikkelen ser jeg nærmere på den daglige mobiliteten. Hvordan den arter seg og hvordan den har utviklet seg for kvinner og menn. Det empiriske grunnlaget er hentet fra de norske reisevaneundersøkelsene fral991/92 og 2001 (RVU).

Forholdet mellom kjønn, transport og daglig mobilitet har tidligere fått ganske stor oppmerksomhet og forskjellen mellom kvinner og menns reisemønstre har blitt ganske omfattende dokumentert. I begynnelsen var denne forskningen først og fremst opptatt av arbeidsreiser. Resultatene viste at kvinner i hovedsak hadde kortere reiser enn menn (Dasgupta 1983, Hanson og Pratt 1988, Hanson og Johnston 1985, Madden 1981). Forklaringene var flere. Tradisjonelle kjønnsroller og kvinners dobbeltrolle ble ofte brukt som en forklaring, flere forskere tilskrev dette kvinners meransvar for husholdet og arbeidet det medførte 
(Ericksen 1977, Faganini 1987, Hanson og Pratt 1988, Hanson og Johnston 1985). Enkelte studier viste at både antall barn (Faganini 1987) og barns alder (Erickson 1977) hadde innvirkning på arbeidsreisens lengde. Kvinner med små barn hadde både kortere arbeidstid og avstand til arbeidet enn andre kvinner. Madden (1981) fant at gifte kvinner med barn hadde de korteste arbeidsreisene også når det ble kontrollert for effekten av inntekt og andre kjennetegn. Andre undersøkelser indikerte at det var kvinnens status som gift, ikke nødvendigvis som mor, som var grunnen til kvinners kortere arbeidsreise (Johnston-Anumonwo 1992). Disse studiene viste at arbeidsdeling innen familien hadde stor betydning både for arbeidstid og arbeidsreisens lengde. Flere studer tydet på at yrkesstatus påvirket arbeidsreisen, det vil sige at ansatte med høy status reiste lenger enn de med lavere status (Sirmans 1977, Gehra og Kuhn 1978). Disse forskjellene viste seg også blant kvinner (Andrews 1978, Faganini 1987, Hanson og Pratt 1988, Villeneuve og Rose 1988), men selv om det var forskjeller mellom yrkesgrupper, var det like-vel forskjeller mellom kvinner og menn innenfor samme statusgruppe (Hanson og Johnston 1985). Tradisjonelt har menn hatt bedre tilgang til bil enn kvinner, og de har brukt den oftere på arbeidsreisen enn kvinner (Guiliano 1979, Hanson og Johnston 1985, Hjorthol 1990, Madden og White 1979, Rutherford og Wekerle 1988). Mangel på transport kan begrense kvinners valgmuligheter på arbeidsmarkedet eller forklare deres situasjon som "cirkaptive riders" (Rutherford og Wekerle op cit) i et utilstrekkelig kollektivsystem. I familier med én bil, er det som regel mannen som bruker den (Hjorthol 2000).

I tillegg til forskningen om forskjeller i arbeidsreiser, er det også gjennomført studier som viser at kvinner har flere reiser som er knyttet til husholdsoppgaver (Hanson og Hanson 1980, Hanson og Johnston 1985, Hjorthol 1998, Rosenbloom 1987), og at kvinner har færre fritidsreiser enn menn. Kjønnsforskjeller finnes også i forhold til kvinners og menns oppfatning av transportmidlene. De kulturelle aspektene ved bilen og kollektivtransporten er også kjønnet. Britiske studier viser at kvinner i mye større grad enn menn føler usikkerhet i forbindelse med bruk av kollektivtransport om kvelden (Lynch og Atkins 1988, Atkins 1990). De kulturelle aspektene ved bilen og det kollektive transportsystemet oppfattes forskjellig av kvinner og menn (Hjorthol 2002a). Kvinner har en mer positiv holdning til buss og trikk enn menn. Bilen oppfattes som mer tilhørende den maskuline sfære enn den feminine (Wachs 1992). Bilen som et maskulint prosjekt finnes også i skandinavisk forskning. Eksemplene er relatert til bruk av bilen, til reklame, medlemskap i bilklubber og bilen som et mestringsobjekt (Hagman 1995, Lamvik 1994, Rosengren 1993).

\section{DAGLIG MOBILITET}

Daglig mobilitet er et resultat av hva mennesker ønsker å gjøre, hva de må gjøre og hvilke hjelpemidler de har til rådighet. For å si det enkelt er det tre grunner til at mennesker reiser:

Fordi de onsker det - de vil skifte sted pga et eller annet; for å møte andre mennesker, reise på ferie, vise fram sin nye bil, ta en tur på sykkelen i det fine været osv.

Fordi de kan - de har tilgang til private transportmidler, som bil, sykkel e.l, eller til et offentlig transportsystem.

Fordi de $m a ̊$ - den romlige organiseringen av sosiale aktiviteter krever at man reiser, og forskjellige forpliktelser krever at man reiser og er til sted på bestemte steder til bestemte tider

John Urry (2003) legger vekt på behovet for fysisk nærhet som grunnlag for å reise. Han mener at å reise har sammenheng med ulike former for forpliktelser knyttet til: 1) legale, økonomiske og familiare forhold (fx arbeidsreise) 2) mindre formelle 
sosiale situasjoner (fx slektsbesøk), 3) objekt (fx undertegning av kontrakt), 4) sted ( $\mathrm{fx}$ ved sjøen, på fjellet) 5 ) hendelse - for å oppleve en konsert, skuespill etc. Daglig mobilitet omfatter alle fem "forpliktelser", men antakelig er de to første av Urrys kategorier de mest omfattende. Urry tar ikke opp mulighetene eller forutsetningene for å reise, noe som jeg skal vise er viktig. Individuelle ressurser utgjør en del av dem. I tillegg vil de tidsmessige og romlige strukturene være viktige. De er både betingelse for sosial handling og resultatet av dem.

I en avstandsinstensiv (Whitelegg 1997) verden, stiller dagliglivets organisering krav til mobilitet for å gjennomføre de ulike aktivitetene. Arbeid, bosted, skole, butikker og rekreasjon er spredt i forskjellige områder, "urban sprawl" karakteriserer de fleste vestlige byer, og betyr at man må bruke en betydelig del av sin hverdag på reising. Daglig mobilitet skaper miljøproblemer. I byer og tettsteder er trafikken den viktigste kilden for både støy og forurensning. Veitrafikken skaper farlige situasjoner, som i en del tilfeller resulterer i skader og død. Angst for ulykker hindrer både barn og voksne i å bruke sykkel eller å spasere. Den økende tendensen til at barn kjøres til barnehage, skole og fritidsaktiviteter kan føre til både økte helseproblemer blant barn (Sleap et al. 1993) og til sosial inkompetanse når det gjelder å klare seg selv på bussen eller trikken (Freund og Martin 1993, Preiss 1989). Bilen og bilrelaterte aktiviteter opptar cirka en fjerdedel av arealet $\mathrm{i}$ byer og tettsteder (Kolbenstvedt et al. 2000). For barn betyr dette at mulighetene til å bruke nabolaget til lek er redusert betraktelig, og legger sterke føringer på foreldres tidsbruk. Utviklingen av den daglige mobiliteten, reiselengder og transportmiddelbruk, vil dermed ha stor betydning både for miljøsituasjonen og ulike sider ved dagliglivet, som kan ha forskjellig betydning for kvinner og menn.

\section{DE SOSIALE FORHOLDENE MELLOM KJØNN}

Forholdet mellom kjønnene er sosialt og kulturelt konstruert og varierer på den måten etter tid og sted. Disse konstruksjonene reflekteres på forskjellige sosiale arenaer. Her vil jeg fokusere på tre områder, som også har transportmessig betydning:

Arbeidsmarkedet

Husholdsarbeid

Ansvaret for barn og eldre

I gjennomsnitt har kvinner hatt lavere inntekt enn menn, en større del av dem er ansatt i helse og omsorgsarbeid, de har færre

Tabell 1: Tidsbruk per dag for kvinner og menn 25-44 àr i timer og minutter (Norge 1971, 1980, 1990 og 2000).

\begin{tabular}{lcccccccc} 
Aktiviteter & \multicolumn{2}{c}{1971} & \multicolumn{2}{c}{1980} & \multicolumn{2}{c}{1990} & \multicolumn{2}{c}{2000} \\
& Menn & Kvinner & Menn & Kvinner & Menn & Kvinner & Menn & Kvinner \\
\hline Lønnsarbeid & 5,32 & 1,44 & 5,10 & 2,25 & 4,51 & 2,53 & 5,05 & 3,18 \\
Husarbeid & 0,33 & 4.33 & 0,43 & 3,09 & 0,42 & 2,25 & 0,48 & 1,52 \\
Omsorgsarbeid & 0,30 & 1,18 & 0,40 & 1,22 & 0,48 & 1,32 & 0,39 & 1,12 \\
Innkjøp & 0,15 & 0,24 & 0,19 & 0,28 & 0,17 & 0,27 & 0,19 & 0,27 \\
\hline
\end{tabular}

Kilde: Vaage 2002 
frynsegoder og kortere arbeidstider. Når det gjelder inntekt har forskjellen mellom kvinner og menn blitt opprettholdt gjennom de siste 15 år (SSB 2002). Fremdeles bruker kvinner mer av sin tid på husarbeid og innkjøp enn menn. De bruker også mer tid på omsorgsarbeid, som i hovedsak består av å ta seg av egne barn. Tabell 1 viser tidsbruk for norske kvinner og menn i aldersgruppen 25-44 år fra 1971 til 2000.

Mens kvinner nesten har fordoblet sin innsats på arbeidsmarkedet, er menns lønnsarbeid noe redusert. Tiden som brukes på husarbeid har blitt drastisk redusert i denne 30-årsperioden, og det er kvinnene som har begrenset innsatsen. Menn har økt sin tidsbruk med 15 minutter på 30 år, noe som på langt nær kompenserer for kvinnenes reduksjon. Kvinner har fremdeles størst ansvar for omsorgsarbeidet i familien, og dette har endret seg relativt lite i perioden. Det samme gjelder også innkjøp; kvinner gjør fremdeles det meste. Resultatene fra tidsbruksundersøkelsene viser at selv om det har vært en radikal forandring på kvinners bruk av tid på lønnsarbeid og husarbeid, har menn i svært liten utstrekning overtatt mer av ansvaret for husholdningens daglige drift. Kvinnene har fortsatt hovedansvaret for familiens interne liv. Endringene i tidsbruk reflekterer også kulturelle endringer. Normene for husarbeid har åpenbart forandret seg i tillegg til at maskinparken på norske kjøkken har økt. Omfanget av ferdigmat har $\varnothing \mathrm{kt}$, støv under sofaen aksepteres lettere og skinnende blanke vinduer er antakelig sjeldnere enn for 30 år siden. Men det ser ut til at normene som er knyttet til foreldreomsorgen har endret seg lite, dersom man tar utgangspunkt i tidsbruken. Fokus på barn i dagens samfunn er tydelig, fx å gi barn 'kvalitetstid', engasjere seg i deres fritidsaktiviteter og sørge for de beste mulighetene (fx øker andelen barn på private skoler i Norge). I vestlige byer har det vært en økning i organiserte aktiviteter for barn på bekostning av barns uorganiserte lek (Valentine og McKendrick 1997). Na- bolaget er ikke lenger barns vanligste utfoldelsesområde, organiserte aktiviteter, som fx sport og musikk, vinner stadig fram. Dette betyr mer transport av barn. Disse utviklingstrekkene har romlige, tidsmessige og økonomiske virkninger på kvinners og menns daglig reiser og transportbruk, som jeg vil vise i de neste avsnittene.

\section{DE NASJONALE REISEVANEUNDERSØKELSENE}

De empiriske analysene i denne artikkelen er basert på de norske reisevaneundersøkelsene (RVU) fra 1991/92 og 2001. De består av tilfeldige utvalg av den norske befolkningen fra 13 år og eldre. I (1991/2) var utvalgsstørrelsen cirka 6000 personer, i 2001 besto utvalget av cirka 20.000 informanter. Svarprosentene var henholdsvis 67,5 prosent og 64,2 prosent. Respondentene ble intervjuet på telefon om deres daglige reiser (reisehensikt, lengde, tidsbruk, bruk av transportmiddel, antall personer i bilen, når og hvor reisen startet og endte), kjennetegn ved husholdet og bakgrunnsopplysninger som utdanning, inntekt, transportressurser og lønnsarbeid.

\section{Tilgang TIL BIL OG FRYNSEgODER}

Tilgang til transportmidler, private eller offentlige, er en viktig forutsetning for å reise selv om cirka 20 prosent av de daglige reisene foregår til fots. Bilen har tradisjonelt tilhørt mannens domene. I 1991/92 hadde cirka 70 prosent av mennene alltid tilgang til bil, det vil sige de hadde både førerkort og kunne bruke bilen når de ønsket.

Blant kvinner var andelen 55 prosent. I 2001 var andelene omtrent de samme. Resultatene tyder på at det ikke har skjedd noen forandring. Ser vi nærmere på de ulike aldersgruppene, får vi et mer differensiert bilde (tabell 2). Mens tilgang til bil varierer ganske lite mellom menn, er forskjellene nye større blant kvinner, især i 1991/92. I løpet av denne ti-årsperioden 
Tabell 2: Forerkort og alltid tilgang til bil for kvinner og menn $i$ ulike aldersgrupper $i$ prosent (Norge 1991/92 og 2001).

Aldersgruppe 1991/92 2001

Menn Kvinner Menn Kvinner

\begin{tabular}{lcccc}
$18-24$ år & 63 & 53 & 51 & 34 \\
25-34 år & 79 & 72 & 76 & 71 \\
35-44 år & 82 & 78 & 84 & 77 \\
$45-54$ år & 87 & 67 & 84 & 75 \\
$55-66$ år & 74 & 48 & 86 & 64 \\
$67-74$ år & 73 & 20 & 84 & 40 \\
$75+$ år & 54 & 9 & 70 & 15 \\
Alle & 70 & 55 & 72 & 56 \\
\hline
\end{tabular}

har kvinner fra 45 år og oppover økt sin tilgang til bil betraktelig, men potensialet for økning i denne gruppa er fremdeles stort. Den største forskjellen finner vi blant de eldste fra 75 år og oppover. Blant de yngste ser vi et interessant fenomen. I perioden har det vært en nedgang i tilgang til bil både blant kvinner og menn, størst blant kvinner. Denne tendensen har også vist seg $\mathrm{i}$ andre skandinaviske land (Hjorthol 2002 b). Forklaringene har vært knyttet til økonomiske faktorer (Kranz og Vilhelmson 1996), økt miljøbevissthet (Ruud 1999), mindre interesse for bil som et kultobjekt (Anderson og Warmark 1999, Sjöberg 2000, Nordbakke 2002) og at flere unge er under utdanning og er bosatt i urbane strøk (Hjorthol 1999, 2002b). Fremdeles er det også forskjell mellom kvinner og menn i de midtre aldersgruppene, og forskjellene har forandret seg lite i løpet av denne tiårsperioden. Det som imidlertid virker helt klart, er at når dagens kohorter av kvinner over 25 år kommer opp i de eldre aldersgruppene, vil forskjellene bli re- dusert både mellom kvinner og mellom kvinner og menn. Hvilken betydning nedgangen i førerkortinnehav blant de yngste vil ha, er for tidlig å si noe om. I tillegg til å ha høyere gjennomsnittsinntekt enn kvinner, har menn også arbeidsrelaterte frynsegoder som gjør det mer attraktivt for dem å kjøre bil enn det gjør for kvinner. I 1991/92 hadde 17 prosent av mennene en eller annen form for bilgodtgjørelse eller firmabil. Tilsvarende andel blant kvinner var 5 prosent. I 2001 var tallene henholdsvis 20 og 6 prosent. Det betyr at arbeidsgiverne fremdeles betaler en ikke ubetydelig del av menns bilreiser.

\section{FORSKJELLER I REISELENGDE OG REISEFORMÅL}

Menn har fremdeles flere reiser enn kvinner (tabell 3), men forskjellen mellom kjønnene har blitt mindre, først og fremst fordi kvinner oftere var i lønnet arbeid i 2001 enn i 1991/92. Dette har betydning for omfanget både av arbeidsreiser og omsorgsreiser. ${ }^{1}$ Menn reiser imidlertid mye lengre enn kvinner. I gjennomsnitt reiser menn omtrent $50 \mathrm{~km}$ per dag, mot kvinners cirka $40 \mathrm{~km}$ per dag. Sammenliknet med 1991/92 har menn økt sin reiselengde med 21 prosent, kvinner med 11 prosent. Kvinners "handlingsrom" er mer begrenset enn menns og det øker mindre. Tid brukt på reiser har endret seg lite i løpet av denne perioden, kvinner har økt sin tidsbruk mer enn menn, så forskjellene mellom kjønnene har avtatt.

Å reise er en nødvendighet for å gjennomføre daglige aktiviteter, og transportsystemet er først og fremst utviklet med tanke på produksjon og arbeidsliv. Dette har konsekvenser i forhold til hvilke formål man trenger transportsystemet til. Som tabell 4 viser, er kvinner og menns reiseformål forskjellige, selv om de har omtrent de samme antall reiser.

De to første reiseformålene er koplet til aktiviteter som må gjøres. Dette er obliga- 
Tabell 3: Antall reiser per dag, $\mathrm{km}$ per dag og minutter per dag for kvinner og menn (Norge 1991/92 og 2001).

\begin{tabular}{lllll}
\multicolumn{2}{c}{$1991 / 92$} & \multicolumn{2}{c}{2001} \\
Antal Km & Min & Antall Km & Min \\
reiser per & per & $\begin{array}{l}\text { reiser per } \\
\text { per }\end{array}$ \\
per dag & dag & $\begin{array}{l}\text { per dag } \\
\text { dag }\end{array}$ & & \\
dag & & & dag
\end{tabular}

Kjønn

$\begin{array}{lllllll}\text { Menn } & 3,4 & 42 & 68 & 3,20 & 51 & 70 \\ \text { Kvinner } & 2,9 & 35 & 55 & 3,09 & 39 & 62\end{array}$

toriske reiser og faller klart inn under Urrys første kategori, som dreier seg om formelle forpliktelser. Omsorgsreisene, fx å følge og hente barn i barnehagen, er også reiser som må gjøres, men her vil det kunne være en diskusjon om hvem som skal gjøres det. Er det fx mor eller far? Urrys kategorisering mister dette viktige aspektet ved reisen - at denne typen forpliktende reise i prinsippet kan gjøres av ulike personer i et hushold eller familie. Omsorgsreisen er et godt eksempel på en obligatorisk reise der spørsmålet om hvem som gjør den er knyttet til sosiale forventninger og normer. Det samme kan man si om innkjøpsreiser, selv om de ikke på samme måten som omsorgsreisene er obligatoriske. Innkjøp av dagligvarer, som dette i hovedsak dreier seg om, er ikke tids- og stedsbundet som samme måte som mange omsorgsreiser, men er knyttet til et husholds fellesoppgaver som er forbundet med sosiale forventninger. Besøk hos slekt og venner er knyttet til de reisene som Urry kategoriserer som sosiale forpliktelser. Dette er ikke obligatoriske reiser, men har frivillig karakter. De er stedsbundne, men tidsmessig kan de variere. Reisene knyttet til fritiden kan plasseres i flere av Urrys kategorier, men de kommer helt klart i den gruppen som jeg har kalt ønskede reiser. Menn har flere arbeids- og tjenestereiser enn kvinner, men kvinner har øt sine arbeidsreiser i perioden. Menn har også flere fritidsreiser enn det kvinner har. Kvinner derimot, har flere omsorgs- og innkjøpsreiser enn menn. De har med andre ord flere av den typen reiser, som i mange tilfeller kunne vært gjort av en annen i husholdet. Forskjellen mellom kvinner og menn har ikke avtatt i perioden. Det er snarere slik at de har blitt forsterket. Dette gjelder særlig omsorgsreisene, der det har vært en betydelig større økning for kvinner enn for menn. Dette viser at kvinnene får stadig større ansvar for familiens sjåførvirk-

Tabell 4: Antall reiser per dag etter formål for kvinner og menn (Norge 1991/92 og 2001).

Reisens formål

$1991 / 92$

2001

\begin{tabular}{lllll} 
& Menn & Kvinner & Menn & Kvinner \\
\hline Lønnsarbeid & 0,71 & 0,40 & 0,79 & 0,57 \\
Tjenesteoppdrag & 0,17 & 0,03 & 0,15 & 0,06 \\
Innkjøp & 0,78 & 0,84 & 0,71 & 0,81 \\
Omsorgsreise & 0,23 & 0,27 & 0,37 & 0,44 \\
Besøk hos slekt og venner & 0,47 & 0,50 & 0,39 & 0,39 \\
Egen fritid & 0,64 & 0,50 & 0,56 & 0,48 \\
\hline
\end{tabular}


somhet. Den økte tilgang til bil i disse aldersgruppene er knyttet til slike oppgaver. Ansvaret for husholdsoppgavene er fremdeles kjønnet. De kulturelle aspektene ved foreldreomsorg (og morsomsorg) som jeg diskuterte tidligere er reflektert i denne typen omsorgsreiser. Økningen i omfanget av slike reiser gjenspeiler blandt andet at en større del av barns aktiviteter foregår utenfor deres lokalmiljø. Økningen kan også være knyttet til tidspress i dagliglivet (Fyhri 2002) og at å kjøre barn er mer bekvemt enn å bruke andre reisemåter (Mackett 2002). For, som jeg viser i neste avsnitt, foregår svært mange av denne typen reiser med bil.

\section{BRUK AV TRANSPORTMIDLER}

Det er fremdeles store forskjeller i reisemåte mellom kvinner og menn, når vi ser alle under ett (tabell 5).

Tabellen viser også at endringen mellom 1991/92 og 2001 er ganske beskjeden. Både blant kvinner og menn har det vært en liten økning i bilkjøring, men forskjellen mellom kjønnene er fremdeles den samme. Ser vi nærmere på forskjellige aldersgrupper, viser det seg at det har vært klar økning i bilbruk for flere (tabell 6). Bortsett fra de aller yngste, 18-24 år, og menn mellom 35 og 44 år, har det vært en øking for alle. Økningen har vært størst blant dem som er 55 år og eldre. For aldersgruppene mellom 25 og 55 år har økningen vært relativt beskjeden. For middelaldrende menn kan det se ut til at bilbruken er stabilisert på cirka 70 prosent. For kvinnene i disse aldersgruppene har økningen vært høyere enn for menn, så forskjellene har avtatt.

I de eldste aldersgruppene har det vært en økning både blant kvinner og menn, men forskjellene mellom kjønnene har økt. Det har det også gjort blant de yngste, der både kvinner og menn har redusert sin bilbruk. Som jeg viste i tabell 2, har denne gruppen fătt dårligere tilgang til bil i perioden og færre av dem hadde førerkort i 2001 enn i 1991/92. Kvinnene bruker bilen til omtrent de samme formål som menn, men det er en klar nivåforskjell. Forskjellen mellom kvinner og menn er minst på omsorgsreisene, der henholdsvis 66 prosent av kvinnene og 76 prosent av mennene kjører bil. Forskjellen er størst på innkjøpsreisene, hvor menn kjører i 68 prosent av tilfellene, mens kvinnene bruker bil på 47 prosent av sine reiser. Spørsmålet er om kvinnene er i

Tabell 5: Reisemåte for kvinner og menn i prosent (Norge 1991/92 og 2001).

Reisemåte

$1991 / 92$

2001

\begin{tabular}{lllll} 
& Menn & Kvinner & Menn & Kvinner \\
\hline Til fots & 18 & 25 & 18 & 25 \\
På sykkel & 7 & 5 & 5 & 4 \\
Kollektivtransport & 7 & 10 & 8 & 10 \\
Bilpassasjer & 7 & 19 & 7 & 17 \\
Bilfører & 59 & 41 & 61 & 44 \\
Annet & 2 & - & 1 & - \\
Sum & 100 & 100 & 100 & 100
\end{tabular}


Tabell 6: Kjorer bil på daglige reiser $i$ prosent. Kvinner og menn. (Norge 1991/92 og 2001).

Aldersgrupper 1991/92

2001

Menn Kvinner Menn Kvinner

\begin{tabular}{lllll}
\hline 18-24 år & 57 & 45 & 46 & 31 \\
25-34 år & 66 & 54 & 64 & 56 \\
$35-44$ år & 70 & 55 & 73 & 59 \\
$45-54$ år & 74 & 47 & 70 & 53 \\
$55-66$ ar & 66 & 31 & 71 & 43 \\
$67-74$ år & 52 & 15 & 61 & 22 \\
$75+$ år & 41 & 4 & 52 & 9 \\
\hline
\end{tabular}

en annen situasjon enn menn når de bruker bil. For å undersøke dette nærmere presenterer jeg multivariate analyser av bilbruk på arbeidsreisen for henholdsvis kvinner og menn for 1991/92 og 2001, der effekten av flere variabler blir testet på samme tid. I tillegg til alder, utdanning, ukentlig arbeidstid, reiselengde og inntekt, er variablene $\mathrm{i}$ analysen knyttet til familiesituasjon, kjennetegn ved bostedet og kvaliteten på kollektivtilbudet.

Familiesituasjonen, området man bor i og kvaliteten på kollektivtilbudet er de viktigste faktorene for om kvinner bruker bil eller ikke på arbeidsreisen. Enslige kvinner og kvinner i parforhold uten barn bruker bil på arbeidsreisen mindre grad enn kvinner med barn. I 1991/92 bruke enslige

Tabell 7: Bruk av bil som sjäfor til arbeidet for menn og kvinner med forerkort 18 àr og eldre (Norge 1991/92 og 2001). Logistisk regresjon, forenkelt presentasjon. Detaljer er vist $i$ vedleggstabell 1.

Variabler i analysen

$1991 / 92$

2001

\begin{tabular}{lll} 
& Menn & Kvinner \\
\hline Reiselengde & $\begin{array}{l}\text { Øker med } \\
\text { reiselengde }\end{array}$ & $\begin{array}{l}\text { Øker med } \\
\text { reiselengde }\end{array}$
\end{tabular}

Alder

Egen bruttoinntekt

Øker med inntekt

Kvinner

Arbeidstid per uke

Øker med arbeidstid

Utdanning

Middels utdanning

Høy utdanning

Lav og

Lav middels utd. utdanning

Kvalitet på

Dårlig

Dårlig

Dårlig

kollektivtransport

kvalitet

kvalitet

Unge

Bostedsområde

Mindre tettsted og spredtbygde strøk

Øker med inntekt

$$
\text { strøk }
$$

Familietype

Enslig

Par med barn

Mindre tettsted og spredtbygde strøk

Par med barn 
menn oftere bil enn andre menn, i 2001 hadde familiesituasjonen ingen betydning for menns bilbruk: Kvinner som bor i storbyområdene, både innenfor bygrensene og i nabokommunene, bruker bilen mindre enn kvinner i resten av landet i 2001. I 1991/92 bruke storbykvinnene bil mindre enn kvinner i resten av landet. For menn hadde bosted ingen betydning for bilbruk på arbeidsreisen i 2001. Betydningen av kvaliteten på kollektivtilbudet har økt i løpet av perioden. Bilbruken er lavere der tilbudet er godt. Effekten av kollektivtilbudet er større for kvinners bruk av bil enn for menns.

Betingelsene for kvinners bruk av bil på arbeidsreisen har endret seg relativt lite i perioden mellom 1991 og 2001. I begynnelsen av det 21. århundret er det fremdeles slik at en familiesituasjon med barn har signifikant innflytelse på om kvinner bruker bil til arbeidet, mens det har ingen betydning for menn. I 1991/92 kombinerte 22 prosent av kvinnene arbeidsreisen med innkjøp av dagligvarer og 9 prosent fulgte barn til eller fra barnehagen eller skolen. De tilsvarende tallene for menn var 15 og 5 prosent. I 2001 var det 25 prosent av kvinnene som gjorde innkjøp i tilknytning til arbeidsreisen og 13 prosent fulgte barn. De tilsvarende andelene for menn var henholdsvis 15 og 6 prosent. Den typiske kvinnelige bilisten (på arbeidsreisen) er relativt ung, hun har barn, bor i en småby eller i spredtbygde områder, kollektivtransporten på bostedet er av dårlig kvalitet. Hun har en rimelig bra inntekt, men ganske lav utdanning. Den typiske mannlig bilist kan være hvem som helst. Han bor i de fleste steder i landet, i alle typer familier, han har lav eller middels utdanning. Sannsynligheten for at han bruker bil øker med inntekten og avtar dersom kvaliteten på kollektivtransporten er meget god.

Kvinner og menns reisemønstre reflekterer deres ulike sosiale posisjoner. Reiseaktiviteten og transportmiddelbruken er et resultat av organisering av dagliglivet, opp- gaver som må gjøres, ting man har lyst til å gjøre og hva man har av ressurser til å gjøre dette. Fremdeles er det slik at hverdagslivet er forskjellig for kvinner og menn. Selv om de aller fleste kvinner har lønnsarbeid, og en større andel av dem arbeider full tid i 2001 enn i 1991/92, er det fremdeles slik at kvinner har hovedansvaret for å gjøre oppgaver for husholdets eller familiens fellesskap. Formålet med de daglige reisene viser dette. Resultatene fra tidsnyttingsundersøkelsene viser at kvinner bruker mindre tid på husholdsarbeid over tid, mens menn bruker noe mer tid på samvær med barn. Dette gir indikasjoner på at fordelingen av husholdsarbeid er under forandring. Prosessen ser ut til å gå langsomt, og har foreløpig hatt liten effekt på den daglige mobiliteten. Kvinners doble rolle, både som yrkesaktiv og som hovedansvarlig for hjemmesfæren viser seg i deres reisemønstre, og er langt på vei en bekreftelse på tidligere forskning.

Studiet av kvinners og menns reisemønstre kan betraktes som et "barometer" på likestillingens tilstand i samfunnet. Disse enkle analysene viser at når det gjelder tilgang til bil har forskjellene mellom kvinner og menn avtatt noe i løpet av 90-tallet, men fremdeles er de signifikante i de fleste aldersgrupper. Bedringen i biltilgang for kvinner har også betydd at kvinnene har $ø k t$ sin sjåførvirksomhet for familien. Det dreier seg om både å kjøre barn til skole og barnehage og til forskjellige fritidsaktiviteter. Mens kvinner har flere reiser for andre, Har menn flere reiser for seg. Selv om forskjellene reduseres, er det fremdeles et stort potensial for økning dersom kvinner skal opp på menns nivå av bilbruk. Når bilen blir mer og mer nødvendig for å klare organiseringen av hverdagslivet og bedre tilgangen til arbeidsmarkedet, er det vanskelig å tro at kvinner ikke ønsker en egen bil. Økningen i tobilshusholdet gir indikasjoner på det. Foreløpig er imidlertid forskjellen mellom kvinner og menns bruk av bil relativt sett større enn deres tilgang til bil. En 
Vedleggstabell 1: Bruk av bil som sjåfor til arbeidet for menn og kvinner med forerkort 18 år og eldre (Norge 1991/92 og 2001). Logistisk regresjon.

Variabler i analysen

$1991 / 92$

2001

B

$\mathrm{B}$

\begin{tabular}{lllll} 
& Menn & Kvinner & Menn & Kvinner \\
\hline Reiselengde &, $019^{* * *}$ &, $038^{* * *}$ &, 001 &, 002 \\
Alder &, 002 &,- 006 &, 003 &,$- 008^{* *}$ \\
Egen bruttoinntekt &, 003 & .026 &, $024^{* *}$ &, $017^{* * *}$ \\
Arbeidstid per uke &, $021 * *$ &, 016 &,- 003 &,- 001 \\
\hline
\end{tabular}

Utdanning 1)

Lav

Middels

Kvalitet på kollektivtransport 2)

Svært god eller god

Nokså god

, $031-, 464$ *

$-, 475 * * *$

$-, 717 * * *$

$-, 046$

$-, 109$

$-, 060$

$-, 364 * * *$

Bostedsområde 3)

Oslo, Bergen, Trondheim

Omegnskommuner til Oslo/Be/Tr

,- 553 ** $\quad-, 739 * *$ *

$-, 082$

$-, 491 * * *$

$-, 421 *$

$-, 310$

$-, 135$

$-, 335 * * *$

\begin{tabular}{lllll}
\hline Familietype 4) & & & & \\
Enslig &, $417^{* *}$ &,$- 387^{*}$ &, 042 &,$- 371^{* * *}$ \\
Par uten barn &, 248 &,- 293 &, 085 &,$- 506^{* *}$ \\
Enslig med barn &, 718 &, 188 &, 263 &, $296^{*}$ \\
\hline Konstant &,- 387 & $1,664^{* * *}$ &, 171 & $1,837^{* * *}$ \\
\hline $\mathrm{N}$ & 1563 & 971 & 6706 & 3811 \\
\hline
\end{tabular}

${ }^{* * *} \mathrm{p}<, 000,{ }^{* *} \mathrm{p}<, 001,{ }^{*} \mathrm{p}<, 05$

Referansekategorier: 1) høy utdanning, universitetsnivå 2) Dårlig eller svært dårlig kvalitet* 3 ) Resten av landet 4) Par med barn.

* Kollektivtilbudet er definert som følger: Svært god tilgang til kollektivtransport: Minst 4 avganger per time på hverdager og under $1 \mathrm{~km}$ til den holdeplassen som vanligvis brukes. God tilgang til kollektivtransport: 2-3 avganger per time på hverdager og under $1 \mathrm{~km}$ til holdeplass, eller minst 4 avganger pr time og $1-1,5 \mathrm{~km}$ til holdeplassen. Middels god tilgang til kollektivtransport: 1 avgang per time på hverdager og under $1 \mathrm{~km}$ til holdeplass, eller 2-3 avganger per time og 1-1,5 km til holdeplassen. Dårlig tilgang til kollektivtransport: Avgang hver annen time eller sjeldnere på hverdager og under $1 \mathrm{~km}$ til holdeplass, eller 1 avgang per time og 1-1,5 km til holdeplassen. Svært dårlig eller ikke noen tilgang til kollektivtransport: Ikke noe kollektivtilbud innen $1,5 \mathrm{~km}$ fra boligen, eller avganger sjeldnere enn hver annen time på hverdager og 1-1,5 km til holdeplassen. 
forklaring kan være at vanen spiller en rolle. Dess mer man er vant til å kjøre bil, jo oftere bruker man den til alle formål. Kvinner har muligens ikke lagt seg til like fastlagte vaner som det menn har. Tradisjonelt har bilinteressen vært større blant gutter og menn enn blant jenter og kvinner. Som vi har vist i disse analysene, prioriterer de unge kvinnene åpenbart ikke anskaffelse av førerkort og bil like mye som de unge mennene. Hvilken betydning det vil kunne ha fremover, er vanskelig å si. Men det er klart at kvinner i større grad enn menn ser på bilen som kun et transportmiddel, noe som trekker i retning av fortsatt lavere bilhold og bilbruk blant kvinner enn blant menn. Dette vil også avhenge av hvilke samfunnsmessige mål man har for transportpolitikken. I dagens situasjon har kvinner en mer positiv holdning til kollektivtransporten enn menn. Men en kollektivtransport som i første rekke er rettet inn mot arbeidslivet, dekker i mindre grad de reiseformålene som har med organisering av hverdagslivet å gjøre. Når kvinner får bedre tilgang til bil, vil det være en stor sannsynlighet for at de vil bruke den til stadig flere formål, særlig dersom kollektivtilbudet ikke gjøres attraktivt for den typen av reiser som kvinner har flest av.

\section{NOTER}

1. En omsorgsreise er en reise der formålet er å følge eller hente barn eller andre. Den overveidende delen av omsorgsreiser handler om å følge barn til ulike aktivieteter.

\section{LITTERATUR}

- Andersson, F., Warmark, M. (1999): Körkort eller inte körkort, vad paiverkar ungdomar i deres val? En intervju och enkätstudie med 18,5-åringar. Cuppsats i psykologi. Högskolan i Dalarne.

- Andrews, H. F. (1978): "Journey to work considerations in the labour force participation of married women", in Regional Studies 12.
- Atkins, S T (1990): "Personal Security as a

Transport Issue: A state of the Art Review", in Transport Review 10/2.

- Dasgupta, M (1983): Travel-to-Work Characteristics of Different Labourforce Groups A survey in Manchester. TRRL Laboratory Report Report 1069, Crowthorne, Berkshire.

. Ericksen, J. (1977): "An analysis of the journey to work for women", in Social problems 24.

- Faganini, J. (1987): Daily commuting time. The stakes for working mothers in France, National Research Council. Transportation Research Record 1135. Washington DC

- Freud, P., Martin, G. (1993): The Ecology of the Automobile. Black Rose Books,

London/Montreal/New York

- Fyhri, A (2002): Barns reiser til skolen. En spørreundersøkelse om reisevaner og trafikksikkerhet på skoleveien. Transportøkonomisk institutt. Rapport 2002/616, Oslo.

- Gera, S. \& Kuhn, P. (1978): Occupation, locirkational patterns and the journey-to-work. Economic Council of Cirkanada. Discussion paper 121, Ottawa.

- Guiliano, G. (1979): "Public transportation and the travel needs of women", in Traffic Quarterly $33 / 4$.

- Hagman, O. (1995): Bilen och naturen $i$ svensk bilreklam. En studie av bilsambällets mytologi Socialantropologiska skrifter, Göteborgs universitet.

- Hanson, S, Hanson, P. (1980): "Gender and urban activity patterns in Uppsala, Sweden", in Geographicirkal Rewiew 70.

- Hanson, S. \& Johnston, I. (1985): “Gender differences in work-trip length. Explanations and implicirkations", in Urban Geography 6/3.

- Hanson, S. \& Pratt, G. (1988): "Spatial dimensions of the gender division of labor in a locirkal labor market", in Urban Geography 9/2.

- Hanson, S. \& Pratt, G. (1995): Gender, work, and space. Routledge, London and New York.

- Hjorthol, R. (1990): Kvinners arbeidsreiser - et viktig premiss for offentlig planlegging Transport$ø$ konomisk institutt. TØI rapport 1990/72, Oslo. - Hjorthol, R. (1998): Hverdagslivets reiser. En analyse av kvinners og menns daglige reiser $i$ Oslo. Transportøkonomisk institutt TØI rapport 391, Oslo.

- Hjorthol, R. (1999): Daglige reiser på 90-tallet. Analyser av de norske reisevaneundersøkelsene fra 1991/92 og 1998/98. Transportøkonomisk institutt. ТØI rapport 1999/436, Oslo.

. Hjorthol, R. (2000): "Same city - different options. An analysis of the work trips of married couples in the metropolitan area of Oslo", in Journal of Transport Geography 8. 
. Hjorthol, R. (2002a): "Cultural aspects of the cirkar and public transport. Men's and women's perception”, in Raumplanung 2002/102.

· Hjorthol, R. (2002b): Ungdom og skoleveiser. Den nasjonale reisevaneundersøkelsen 2001. Transportøkonomisk institutt TØI rapport 2002/597, Oslo. - Johnston-Anumonwo, I. (1992): "The influence of household type on gender differences in work trip distance", in Professional Geographer 44/2.

- Johnston-Anumonwo, I. (1997): "Race, gender, and constrained work trips in Buffalo, NY, 1990", in Professional Geographer 49/3.

- Kolbenstvedt, M., Solheim, T., Amundsen, A. (2000): Miljøhandboken - trafikk og miljøtiltak I byer og tettsteder. Transportøkonomisk institutt 2000, Oslo.

- Kranz, L.-G., Vilhelmson, B. (1996): Förändringar av den dagliga rörligheten i Sverige 19781994. Kulturgeografiska institutionen, Göteborgs Universitet.

- Lamvik, G. M. (1994): Et eventyr på hjul. Et antropologisk blikk på amcirkar-kulturen. Report nr 21. Centre for Technology and Society, The University in Trondheim.

- Lynch, G, Atkins S. (1988): "The influence of personal security fears on women's travel patterns", in Transportation 15.

- Mackett, R. L. (2002): "Increasing cirkar dependency of children. Should we be worried?", in Municipal Engineer 151/1.

- Madden, J. F. \& White, M. J. (1979): Women's work trips. An empiricirkal and theoreticirkal overview in women's travel issues. Research needs and priorities. US Dept of Transportation. Washington, DC.

- Madden, J. F. (1981): "Why women work closer to home", in Urban Studies 18.

- Nordbakke, S. (2002): Førerkort og bilbruk blant ungdom på 90-tallet. Tegn på endringer $i$ ungdoms reisevaner? Transportøkonomisk institutt. TØIrapport 2002/564, Oslo.

- Preiss, D. (1989): "Frauen - Kinder - Auto Träume", in Beckmans m fl: Welche Freiheit brauchen wie? Zur Psychologie der AutoMobilen Gesellschaft. Vas in der Elefanten Press. Berlin.

- Rosenbloom, S (1987): "The impact of growing children on their parents' travel behaviour: a comparative analysis", in Transportation Research Record 1135.

- Rosengren, A. (1993): Some notes of the male motoring world in a Swedish community. Paper at the workshop "The cirkar and its environments. The past, present and future of the motorcirkar in Europe", Trondheim, May 6-8, 1993.

- Rutherford, B. \& Wekerle, G. (1988):

"Cirkaptive rider, cirkaptive labor: spatial constraint on women's employment", in Urban Geography.

- Ruud, A. (1999): Bilismen er skadelig for miljøet - men spiller jeg noen rolle? Transportøkonomisk institutt. ТØI rapport 1999/424, Oslo.

- Sirmans, C. F. (1977): "Determinants of journey to work flows. Some empiricirkal evidence", in The Annals of Regional Science 11/1.

- Sjöberg, A. (2000): Fürdsätt. En etnologish studie om resvanor, miljömedvetande och livsstilar bland unga $i$ Göteborg. Etnologiska föreningen i Västsverige, Göteborg.

- Sleap, M., Warburton, P. (1993): “Are primary school children gaining heart health benefits from their journey to school?", in Child: care, health and development 19.

- Statistisk sentralbyrå (SSB) (1998): Samferdselsstatistikken. Oslo-Kongsvinger.

- Statistisk sentralbyrå (SSB) (2002):

http://www.ssb.no/norge/inntekt/

. Urry, J (2003): "Social networks, travel and talk", in British Journal of Sociology 54/2.

. Valentine, G., McKendrick, J. (1997): “Childrens's outdoor play; exploring parental concerns about children's safety and the changing nature of childhood", in Geoforum 28.

- Villeneuve, P. \& Rose, D. (1988): “Gender and the separation of employment from home in metropolitan, Montreal, 1971-1981", in Urban Geography $9 / 2$.

- Vaage, O. F. (2002): Til alle dognets tider. Tidsbruk 1971-2000 (Time use 1971-2000). Statistics Norway. Statisticirkal analyses 52. Oslo-Kongsvinger.

. Wachs, M. (1992): "Men, women, and urban travel. The Persistance of Separate Spheres", in Wachs, M. and Crawford, M. (eds.): The Cirkar and the City. The Automobile, the Built Environment and Daily Urban Life. University of Michigan Press, Ann Arbor, MI.

-Whitelegg, J. (1997): Criticirkal Mass. Transport, Environment and Society in the Twenty-first Century. Pluto Press, London/Chicago IL.

\section{SUMMARY}

Women and men's travel patterns reflect their different social positions. The travel activity and transport modes are a result of the organisation of everyday life and access to resources. Still men and women's daily lives differ. Even though most women have paid work and a greater part of them work full- 
time in 2001 than in 1991-92, women to a greater extent than men are responsible for the "management" of the household, also in families without small children. The purposes of daily travel and mobility demonstrate this fact. As long as the distribution of tasks between genders within households are main- tained, differences will also be reflected in travel patterns.

Randi Johanne Hjorthol, dr.philos., forskningsleder

Transportanalyser og regionale studier Transportøkonomisk institutt Oslo 